\title{
MECHANICAL PROPERTIES OF POLYAMIDE/CARBON-FIBER-FABRIC COMPOSITES
}

\author{
MEHANSKE LASTNOSTI KOMPOZITNE TKANINE IZ \\ POLIAMID/OGLJIKOVIH VLAKEN
}

\section{Cristina-Elisabeta Pelin ${ }^{1,2}$, George Pelin ${ }^{1,2}$, Adriana Ştefan1, Ecaterina Andronescu², Ion Dincă ${ }^{1}$, Anton Ficai $^{2}$, Roxana Trușcă ${ }^{3}$}

${ }^{1}$ National Institute for Aerospace Research "Elie Carafoli" Bucharest- Materials Unit, 220 Iuliu Maniu Blvd, 061126 Bucharest, Romania 2University Politehnica of Bucharest, Faculty of Applied Chemistry and Materials Science, 1-7 Gh. Polizu St., 011061 Bucharest, Romania ${ }^{3}$ S.C. METAV Research \& Development S.A., 31 C.A. Rosetti St., 020011 Bucharest, Romania

bancristina@gmail.com, ban.cristina@incas.ro

Prejem rokopisa - received: 2015-07-01; sprejem za objavo - accepted for publication: 2015-09-10

doi: $10.17222 / \mathrm{mit} .2015 .171$

\begin{abstract}
This paper presents the production of carbon-fiber-fabric-reinforced laminated composites based on a polyamide 6 matrix using a multiple-stages technique that involves polymer dissolution in formic acid followed by fabric impregnation and high-temperature pressing. The polyamide/solvent ratio's influence on the interface and mechanical properties is discussed, analyzing three PA6 weight contents of $(10,20$, and 30$) \%$ in a formic acid solvent. The mechanical behavior of the obtained laminated composites is evaluated using tensile and 3-point bending tests and the fracture cross-section is analyzed using microscopy investigation techniques in order to evaluate the fiber-matrix interface and the composite fracture mechanism. The results show that the best mechanical performance is obtained when using a solution of $20 \%$ mass fraction of polyamide in formic acid, as this leads to the formation of a uniform polymer layer that is able to completely embed the fibers that constitute the fabric and create a strong mechanical interface within the composite.

Keywords: polyamide 6, carbon fiber, mechanical properties, polymer/solvent ratio, mechanical interface
\end{abstract}

Članek predstavlja izdelavo laminatnega kompozita na osnovi poliamida 6, ojačanega s tkanino iz ogljikovih vlaken, z uporabo večstopenjske tehnike, ki vključuje raztapljanje poliamida v mravljinčni kislini ter impregnacijo tkanine in stiskanje pri visoki temperaturi. Razložen je vpliv razmerja poliamid/topilo na stik in mehanske lastnosti, z analizo treh masnih vsebnosti PA6 (10, $20,30) \%$ v mravljinčni kislini. Mehansko obnašanje dobljenega laminiranega kompozita je ocenjeno z nateznim preizkusom in s 3-točkovnim upogibnim preizkusom, presek preloma pa je analiziran z mikroskopsko tehniko, da bi ocenili stik z vlaknato osnovo in mehanizem preloma kompozita. Rezultati kažejo, da je najboljša mehanska zmogljivost dosežena pri uporabi raztopine z $20 \%$ masnim deležem poliamida v mravljinčni kislini, ker to povzroči nastanek enakomernega polimernega sloja, ki lahko popolnoma obda vlakna tkanine in ustvari močan mehanski stik v kompozitu.

Ključne besede: poliamid 6, ogljikovo vlakno, mehanske lastnosti, razmerje polimer/topilo, mehanski stik

\section{INTRODUCTION}

In recent decades the use of composite structures in both aeronautic and automotive applications has increased tremendously. Nowadays, composites represent approximately $50 \%$ of the structure of the Airbus A350 XWB and the Boeing 787 Dreamliner, resulting in 20-25 $\%$ reduction in fuel consumption. ${ }^{1}$ Most composite structures are based on thermoset matrix fiber composites, but nowadays there is an increasing interest in replacing the thermoset with a thermoplastic matrix. This trend is due to problems arising from thermoset composites, such as the high costs of raw materials, high energy consumption, extended processing times, non-visible damage, complex repair procedures, recycling difficulties and significant amounts of scrap. ${ }^{2-3} \mathrm{~A}$ thermoplastic matrix offers facile recycling possibilities, lower costs and more flexible processing routes ${ }^{3-6}$, making them a promising solution for the shortcomings of thermoset composites.

Commercial carbon-fiber-fabric-based composites for the transport industry obtained using melt and solvent impregnation with thermoplastic matrixes use PEEK, PPS or $\mathrm{PEI}^{7-8}$, which are high-performance polymers that require over $300{ }^{\circ} \mathrm{C}$ for the processing temperature, leading to high costs. This study focuses on an engineering polymer, with a high potential, i.e., polyamide 6. Most literature studies present polyamide 6 composites reinforced with short fibers (carbon, glass or aramid) processed by melt extrusion ${ }^{9-12}$, a few studies present fabric-reinforced polyamide 6 composites ${ }^{13-14}$, because of the technological processing difficulties arising from fabric-impregnation issues generated by the molten polymer and fiber wet out. ${ }^{15}$ Moreover, the data concerning the optimum solution viscosity range and the optimum polymer/solvent ratio when using the solvent-impregnation method is very briefly discussed, although its importance is underlined ${ }^{16-18}$, as the rheological properties of the matrix are important for establishing the composite's processing parameters. This paper presents the production of carbon-fiber-fabric-reinforced polyamide 6 matrix laminated composites using polymer dissolution followed by fabric solvent impregnation, solvent removal 
and thermal pressing. The processing and final properties of fabric-reinforced composites depend on several factors, one of them being the viscosity of the matrix used to impregnate the fabric. In this context, the novelty of the study is represented by an optimization study concerning the PA6/formic acid (polymer/solvent) ratio's direct influence on the mechanical properties of the final composites, analyzing the solution's viscosity and its direct effect on the fiber/matrix interface and, consequently, on the failure mode of the composites. The mechanical behavior of the obtained laminated composites was evaluated using tensile and 3-point bending tests, the fracture cross-section being analyzed using microscopy techniques to evaluate the fiber-matrix interface and the composite fracture mechanism and to establish the optimum polymer content for the impregnation solution. The results indicate that at an optimum polymer/solvent ratio of $20 \%$ of mass fractions, the obtained materials possess the highest tensile and flexural properties.

\section{EXPERIMENTAL SECTION}

\subsection{Materials}

The matrix was polyamide 6 (PA6) pellets supplied by SC ICEFS Săvineşti, while the solvent was formic acid $85 \%$ analytical grade, purchased from Chemical Company, Romania. The reinforcing agent was a carbon-fiber-fabric twill weave (FC) produced by Chemie Craft, France, $3 \mathrm{~K}$ warp, with $193 \mathrm{~g} / \mathrm{m}^{2}$ fabric areal weight and $1.7 \mathrm{~g} / \mathrm{cm}^{3}$ fiber density.

\subsection{Obtaining process}

The procedure resembles a process involving fabric impregnation with thermoset resins, but it is adjusted to allow the use of polyamide pellets as the raw material. The dried polymer pellets were dissolved in $85 \%$ formic acid in three different concentrations, i.e., 1(0, 20 and 30) $\%$ (polymer weight/solvent volume), under mechanical stirring for $4 \mathrm{~h}$. Each ply of the carbon-fiber fabric was impregnated with the solution and stacked up in groups of five layers. The solvent was removed at room temperature for $48 \mathrm{~h}$ and additional traces were removed at $80-100{ }^{\circ} \mathrm{C}$ for $8 \mathrm{~h}$. Each laminated composite was pressed using a CARVER hot platens press, following an established temperature program, with a linear temperature increase from $25{ }^{\circ} \mathrm{C}$ to $230{ }^{\circ} \mathrm{C}$ and 5 min dwell periods at $(230,235,240$ and 245$){ }^{\circ} \mathrm{C}$. Because the fabric layers were semi-impregnated with polymer after the solvent's removal, the high-temperature pressing did not generate impregnation difficulties that appear during standard polymer-melt impregnation because of the fiber wet-out difficulties. ${ }^{19}$ The cooling took place under pressure down to room temperature. There were obtained laminated plates differing in the PA6 content solution used, referred to as PA6(10\%)/5FC, PA6(20\%)/5FC and PA6(30\%)/5FC, with an average fiber volumetric ratio of
$66 \%$, that were processed into tensile and flexural shape specimens.

\subsection{Testing and characterization}

The viscosity of the different concentration solutions used for the impregnation was measured using an Ubbelohde capillary-tube viscometer (Cannon CT-1000). The PA6 matrix was subjected to FTIR spectroscopy analysis (ThermoiN10 MX Mid Infrared FT-IR Microscope) operated in ATR mode and scanning electron microscopy (QUANTA INSPECT F). The carbon-fiber laminates were mechanically tested (INSTRON 5982 machine) in tensile conditions according to SR EN ISO $527-2^{20}$ at a $5 \mathrm{~mm} / \mathrm{min}$ tensile rate on dumbbell specimens and flexural tests, according to SR EN ISO $14125^{21}$ at $2 \mathrm{~mm} / \mathrm{min}$, conventional deflection and span length on rectangular specimens. The fracture cross-section was analyzed using SEM and the fracture mode was evaluated using optical microscopy (Meiji 8500).

\section{RESULTS AND DISCUSSION}

\subsection{Viscosity measurement}

The solutions containing different contents of dissolved polymer used to impregnate the fabric has to have optimum viscosity, as it distributes the polymer through the fibers. ${ }^{22}$ The effect of the PA6 content dissolved in formic acid on the kinematic viscosity of the solution was studied at room temperature. Figure 1 presents the kinematic viscosity values of the solutions with three different PA6 weight contents, after $4 \mathrm{~h}$ of mechanical stirring. The viscosity increases dramatically with polymer content, from $34.1 \mathrm{~mm}^{2} / \mathrm{s}$ for $10 \%$ PA6 in formic acid to $173 \mathrm{~mm}^{2} / \mathrm{s}$ for $20 \%$ and $898 \mathrm{~mm}^{2} / \mathrm{s}$ for $30 \%$. As the polymer content is increased, the viscosity increases exponentially by approximately five times compared to the

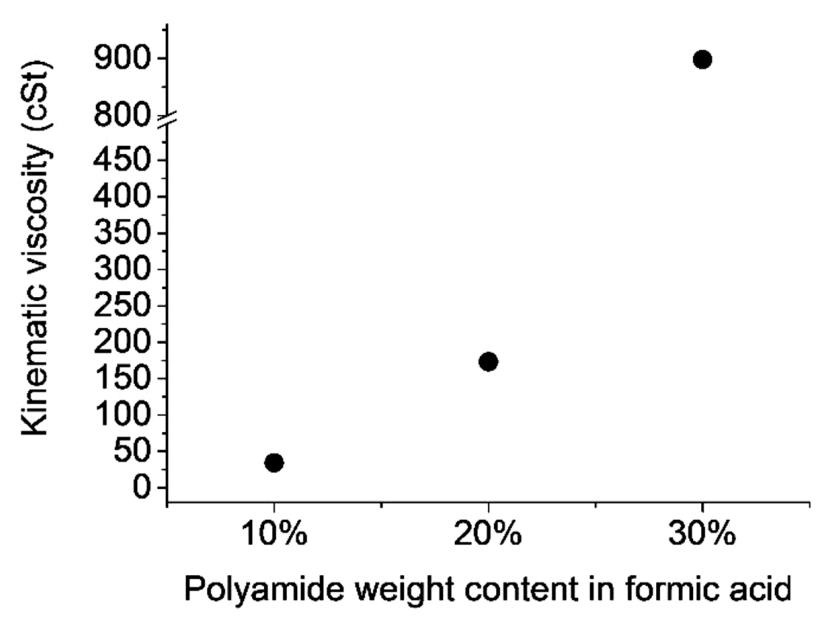

Figure 1: Kinematic viscosity as a function of polyamide 6 weight content in an $85 \%$ formic acid solution

Slika 1: Odvisnost kinematične viskoznosti od vsebnosti poliamida 6 $\mathrm{v}$ raztopini $85 \%$ mravljinčne kisline 


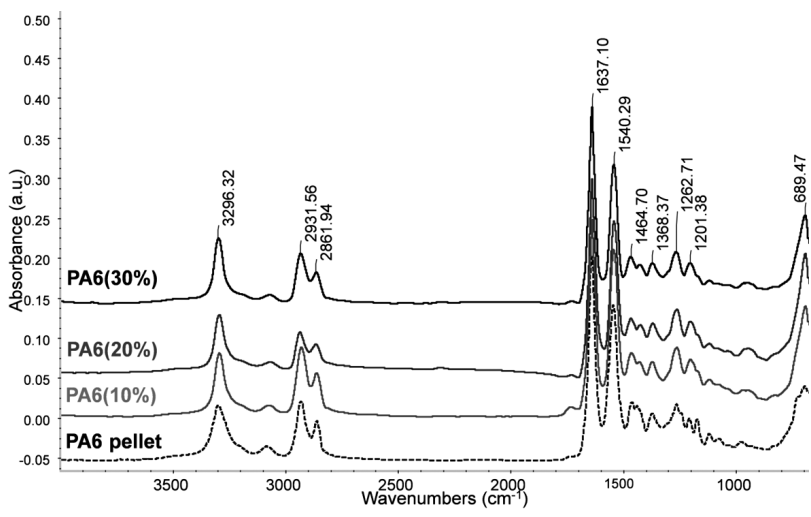

Figure 2: FTIR spectra of the pure PA6 pellet and dried samples based on different PA6 contents dissolved in $85 \%$ formic acid: PA6 $(10 \%)$, PA6 $(20 \%)$, PA6 $(30 \%)$

Slika 2: FTIR-spektri čistega peleta PA6 in posušenih vzorcev z različno vsebnostjo PA6, raztopljene v $85 \%$ mravljinčni kislini: PA6 $(10 \%)$, PA6 $(20 \%)$, PA6 $(30 \%)$

previous value. The dramatic increase for the $30 \%$ content is due to the fact that this value is very close to the homogenous phase-formation limit of a polyamide/formic acid system. ${ }^{23-27}$ The rheological properties affect the impregnation degree and the fiber/matrix interface. If the impregnating solution viscosity is too low, it will pass through the fabric, resulting in polymer coverings that are too thin, while a too high viscosity will not ensure uniform and large fiber-matrix contact surfaces, as any penetration through the fibers will be difficult. ${ }^{28}$

\subsection{FTIR spectroscopy}

FTIR spectroscopy was performed on polyamide films obtained after solvent removal from the three different solution concentrations to evaluate the chemical structure and the eventual solvent traces. Figure 2 presents the spectra of the three PA6 samples compared to a pure PA6 pellet, all the spectra showing the characteristic peaks of polyamide $6 .{ }^{29,30}$ There are no significant changes in the spectra of the samples compared with the pure pellet, as no supplementary peak appears, and there are no traces of unremoved solvent, confirming that the polyamide's chemical structure was not altered by the solvent's presence and it was fully dissolved. The small modification of the bands from $(689.5,1201.4$ and 1464.7) $\mathrm{cm}^{-1}$ can be assigned to the restructuring of the polymer as a result of solubilization followed by crystallization. ${ }^{31}$ The $1200 \mathrm{~cm}^{-1}$ and $1465 \mathrm{~cm}^{-1}$ peaks correspond to the amide $\mathrm{V}$ and $\mathrm{CH}_{2}$ bending vibrations, respectively, in polyamide $\alpha$ or $\beta$ form, which is commonly obtained when the processing of PA6 involves slow cooling ${ }^{32}$, as is the case here.

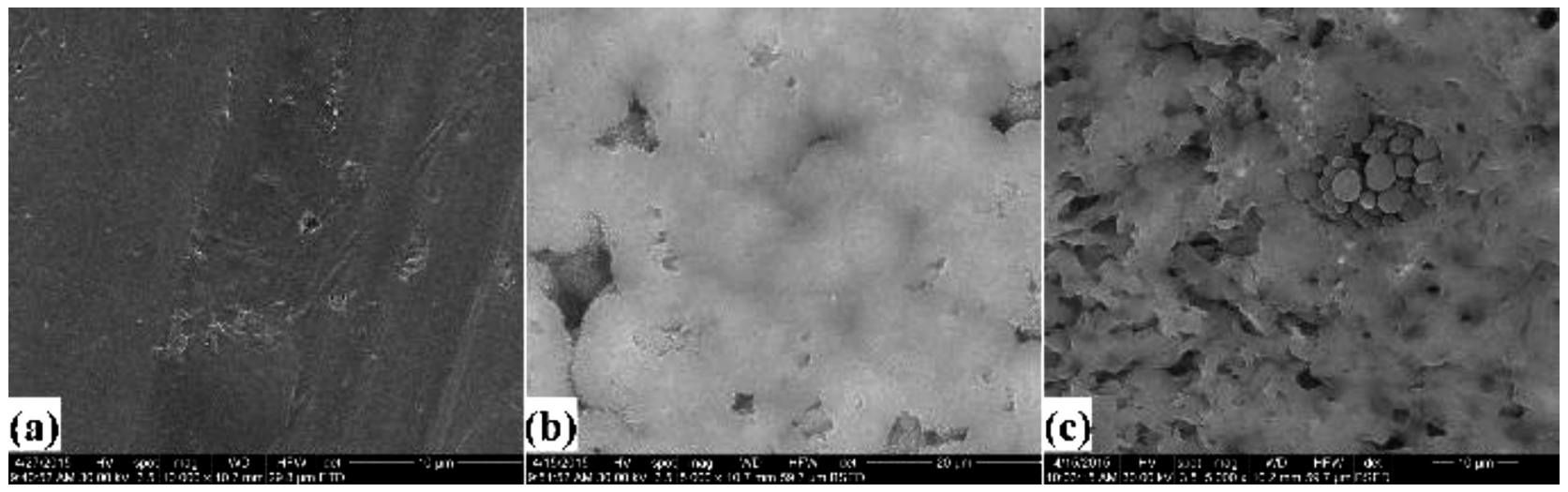

Figure 3: SEM images of matrix samples used to form the laminated composites: a) PA6(10\%), b) PA6(20\%), c) PA6(30 \%) Slika 3: SEM-posnetki osnove vzorcev, uporabljenih za laminiran kompozit: a) PA6 (10 \%), b) PA6 (20 \%), c) PA6 (30 \%)
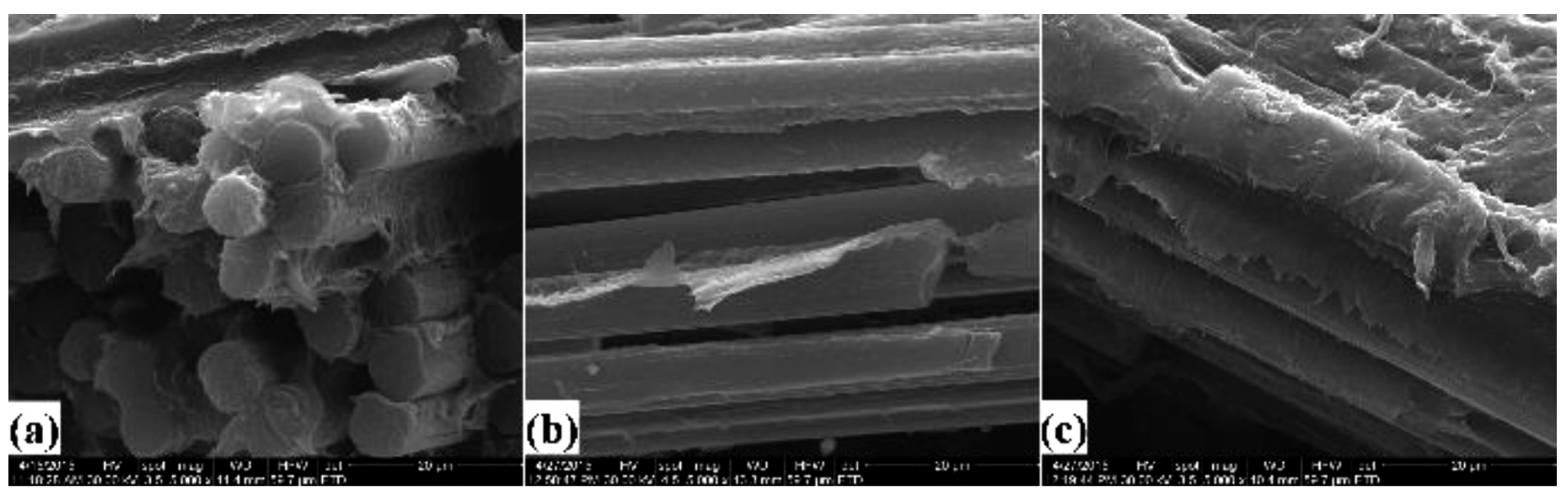

Figure 4: SEM images of the fracture cross-section of laminated composites: a), b) PA6(10\%)/5FC, c) PA6(20\%)/5FC

Slika 4: SEM-posnetki preseka preloma laminiranega kompozita: a), b) PA6 (10\%)/5FC, c) PA6 (20 \%)/5FC 


\subsection{SEM analysis}

SEM analyses were performed on the matrix samples in the form of films to evaluate the morphology and homogeneity. Figure 3 presents the images of dried samples obtained after the dissolution of (10, 20 and 30) \% PA6 into formic acid. As the PA6 content increased up to $30 \%$, there are visible areas of undissolved polymer; this higher concentration value being close to the weight content limit of PA6 in formic acid ${ }^{23-26}$, it probably needs different process parameters for a complete dissolution (e.g., a longer homogenization time).

SEM investigations were performed on the fracture cross-section of the tensile tested laminates. Figure 4 illustrates the samples with a matrix obtained by dissolving $10 \%$ PA6 (Figure 4a and 4b) and $20 \%$ PA6 (Figure 4c). In PA6(10\%)/5FC (Figure 4a) there are several areas where a thin polymer layer uniformly covers the fibers of the fabric, but there are also a few areas where the polymer layer is partially detached from the fiber surface and there are uncovered fibers (Figure 4b). The difference is significant for PA6 $(20 \%) / 5 \mathrm{FC}$, in which case the polymer is distributed in a solid layer that covers the entire fiber surface, but its thickness is not as uniform as in PA6(10\%)/5FC. Each carbon fabric ply is covered with its own polymer layer. The polymer ductile fracture is distinguished from the fiber's fragile fracture.

\subsection{Mechanical testing}

Table 1 illustrates the average values of the strength and elasticity modulus, obtained after tensile and flexural testing of the obtained composites based on five carbon fabric plies. The highest mechanical performance in both the tensile and flexural testing is presented by the sample

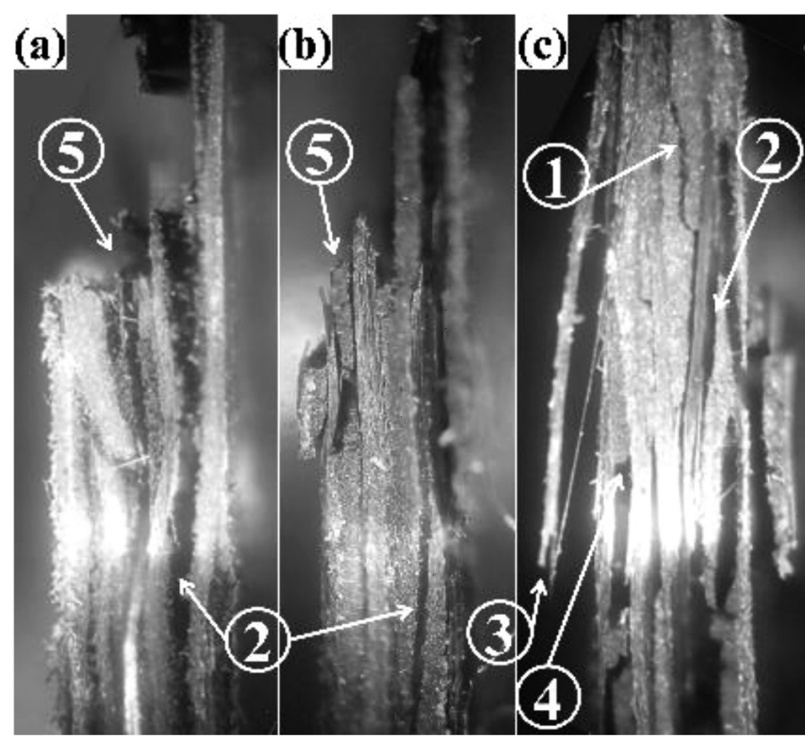

Figure 5: Fracture regions of tensile-tested specimens: a) PA6 $(10 \%) / 5 \mathrm{FC}$, b) PA6 $(20 \%) / 5 \mathrm{FC}, \mathrm{c}) \mathrm{PA} 6(30 \%) / 5 \mathrm{FC}$

Slika 5: Področja preloma nateznih preizkušancev: a) PA6 $(10 \%) / 5 \mathrm{FC}, \mathrm{b})$ PA6 $(20 \%) / 5 \mathrm{FC}, \mathrm{c})$ PA6 (30 \%)/5FC based on PA6(20\%). PA6(20\%)/5FC has a $60 \%$ higher tensile strength compared to PA6(10\%)/5FC, while the flexural strength is approximately $70 \%$ higher. These samples also have a superior rigidity, showing a modulus of elasticity that is higher by $35-40 \%$. The PA6(30\%)/5FC samples showed lower tensile and flexural strengths and tensile moduli compared with PA6(20\%)/5FC, but higher than the PA6(10\%)/5FC, while the flexural modulus had the lowest average value for the entire series. These inconsistent results in PA6(30\%)/5FC are most likely due to the high viscosity of the impregnating solution that was probably not able to uniformly distribute on the surface of the fiber fabric, supplemented by possible undissolved polymer sites, which although they were melted during thermal pressing, could also lead to non-uniform polymer layer sites at the microscopic level. These issues generate inhomogeneity and stress-concentration sites that decrease the rigidity. ${ }^{33-34}$

Table 1: Mechanical properties of composites based on PA6 (dissolved in different contents relative to the solvent) and five plies of carbon fiber fabric

Tabela 1: Mehanske lastnosti kompozita na osnovi PA6 (raztopljene različne količine $\mathrm{v}$ topilu) in petih plasti tkanine iz ogljikovih vlaken

\begin{tabular}{|c|c|c|c|c|}
\hline Sample & $\begin{array}{c}\text { Tensile } \\
\text { strength } \\
(\mathrm{MPa})\end{array}$ & $\begin{array}{c}\text { Young's } \\
\text { modulus } \\
(\mathrm{GPa})\end{array}$ & $\begin{array}{c}\text { Flexural } \\
\text { strength } \\
(\mathrm{MPa})\end{array}$ & $\begin{array}{c}\text { Young's } \\
\text { flexural } \\
\text { modulus } \\
(\mathrm{GPa})\end{array}$ \\
\hline PA6(10\%)/5FC & 339.2 & 45.5 & 436.7 & 38.3 \\
\hline PA6(20\%)/5FC & 540.5 & 63.6 & 732.6 & 51.4 \\
\hline PA6(30\%)/5FC & 505 & 56.3 & 571.6 & 38.1 \\
\hline
\end{tabular}

Overall, the mechanical results show that all the obtained carbon fabric/PA6 laminated samples are superior to the ones exhibited by long-carbon-fiber-reinforced PA6 $6^{35-37}$ that show a tensile strength between 240 and $300 \mathrm{MPa}$, a flexural strength between 330 and $500 \mathrm{MPa}$, and Young's modulus in the range 25-40 GPa for tensile and 20-30 GPa for flexural. Also, PA6(20\%)/5FC mechanical properties are comparable with those presented by carbon-fiber-fabric-epoxy composites ${ }^{38}$ with extended applications in aeronautics.

\subsection{Fractography}

Optical microscopy images were recorded on the fracture region of the laminated samples to establish the fracture mechanisms that led to the failure and to evaluate their behavior when tested under tensile and flexural loads. Figure 5 presents the fracture region of representative specimens from each sample tested in tensile. The identified fracture mechanisms are marked, all of them being classified as classical mechanisms presented by ${ }^{39-40}$ : (1) crack propagation, (2) layer de-bonding, (3) fiber breakage, (4) fiber pull-out, (5) ply breakage. The PA6(10\%)/5FC and PA6(20\%)/5FC fractures resemble as three layers are broken by fiber breakage in the same area, the fracture causing layer de-bonding to the next 


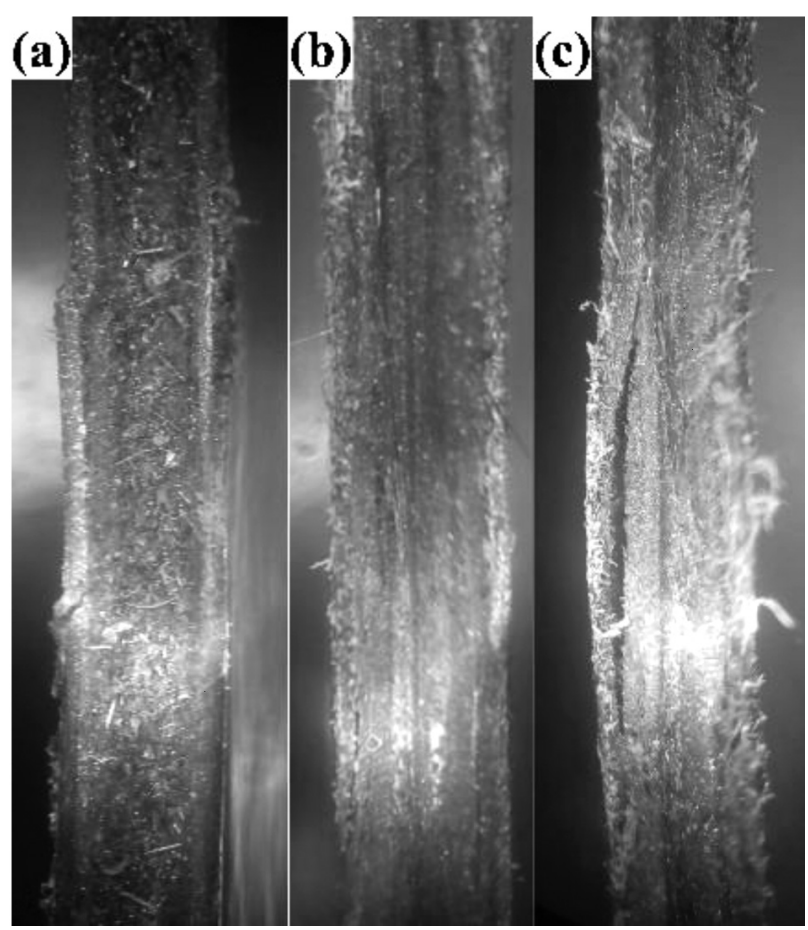

Figure 6: Fracture regions of flexural-tested specimens: a) PA6 $(10 \%) / 5 \mathrm{FC}$, b) PA6 $(20 \%) / 5 \mathrm{FC}$, c) PA6 (30 \%)/5FC Slika 6: Področje preloma upogibnih preizkušancev: a) PA6 $(10 \%) / 5 \mathrm{FC}$, b) PA6 $(20 \%) / 5 \mathrm{FC}$, c) PA6 (30\%)/5FC

layers, with more pronounced de-bonding in PA6(10\%)/5FC. PA6(30\%)/5FC presented the most destructive failure, involving several mechanisms including fiber pull out and interlayer crack propagation, leading to delaminated areas. This can be explained by the high viscosity of the solution that led to non-uniform matrix layers, creating stress-concentration sites. In flexural testing (Figure 6), PA6(10\%)/5FC and PA6(20\%)/5FC did not present any layer rupture until conventional deflection, but the PA6(30\%)/5FC presented the rupture of one external layer that de-bonded on a longer length. It is important to mention that although PA6(10\%)/5FC presented in general the lowest mechanical performance, its fracture mode was not as destructive as for PA6(30\%)/5FC. The optical images complement both the mechanical test results and the SEM studies.

\section{CONCLUSIONS}

The study presents the production of carbon-fabric-reinforced laminated composites based on the engineering polymer polyamide 6 as the matrix using a multiple-stages technique that involves fabric solvent impregnation with a formic acid solution that contains different contents of dissolved polymer, solvent removal and high-temperature pressing. The aim of the study was to evaluate the polymer/solvent (PA6/formic acid) ratio's influence on the mechanical interface within the compos- ite and on the mechanical properties. Three polymer contents in formic acid were used (10, 20 and 30) \% weight/volume, with the rheology tests showing that the solution viscosity increases exponentially. A lower content solution led to a slightly uniform polymer layer that covered the fibers of the fabric, ensuring large contact areas, but because the thin layer was too weak, the laminates' mechanical performance was lower. The highest content solution (30\%) had an extremely high viscosity and most likely did not distribute uniformly, probably generating stress-concentration sites that resulted in a very destructive failure during the mechanical testing.

The study concludes that the optimum content is $20 \%$ polymer dissolved into the solvent, as it leads to medium-viscosity solution that supports polymer penetration through the fibers and forms polymer layers with suitable thickness and uniformity on the fiber surface. This ensures high contact areas, a strong fiber-matrix interface and, consequently, an optimum fiber-matrix load transfer, leading to high mechanical performances in tensile and bending and failure modes that do not exhibit a high degree of delamination. The results show that at an optimum polymer/solvent ratio, these composites can represent potential solutions as materials for high mechanical performance in aeronautics and automotive applications.

\section{Acknowledgments}

This work was funded by the Sectoral Operational Programme Human Resources Development 2007-2013 of the Ministry of European Funds through the Financial Agreement POSDRU/159/1.5/S/132397 and by Romanian Ministry of Education through the PN-II-PT-PCCA168/2012 project: "Hybrid composite materials with thermoplastic matrices doped with fibres and disperse nano fillings for materials with special purposes".

\section{REFERENCES}

${ }^{1}$ T. Chady, Airbus Versus Boeing-Composite Materials: The sky's the limit..., Le Mauricien, September 2013, http://www.lemauricien.com/, 15.6.2015

${ }^{2}$ M. Mrazova, Advanced composite materials of the future in aerospace industry, Incas Bulletin, 5 (2013) 3, 139-150, doi:10.13111/ 2066-8201.2013.5.3.14

${ }^{3}$ B. Money, Moving from thermosets to thermoplastics, Aerospace Engineering Magazine SAE International 2010, http://articles.sae.org/8547, 29.6.2015

${ }^{4}$ A. Pereira da Costa, E. C. Botelho, M. L. Costa, N. E. Narita, J. R. Tarpani, A review of welding technologies for thermoplastic composites in aerospace applications, Journal of Aerospace Technology and Management, 4 (2012) 3, 255-265, doi:10.5028/jatm.2012. 04033912

${ }^{5}$ J. D1'az, L. Rubio, Development to manufacture structural aeronautical parts in carbon fibre reinforced thermoplastic materials, Journal of Materials Processing Technology, 143-144 (2003), 342-346, doi:10.1016/S0924-0136(03)00450-3 


\section{C.-E. PELIN et al.: MECHANICAL PROPERTIES OF POLYAMIDE/CARBON-FIBER-FABRIC COMPOSITES}

${ }^{6}$ J. Pora, Composite Materials in the Airbus A380 - From History to Future, Proc. of the 13th International Conference on Composites (ICCM-13), Beijing, China 2001, 1-10

${ }^{7}$ A. C. Long, Composites Forming Technologies, 1st ed., CRC Press-Woodhead Publishing Ltd., Cambridge 2007, 261

${ }^{8} \mathrm{R}$. Vodicka, Thermoplastics for airframe applications: a review of the properties and repair methods for thermoplastic composites, Defense Science and Technology Organization - Australian Government of Defense, Report no. DSTO-TR-0424, 2006

${ }^{9}$ E. Lafranche, P. Krawczak, J. P. Ciolczyk, J. Maugey, Injection moulding of long glass fibre reinforced polyamide 6-6: guidelines to improve flexural properties, Express Polymer Letters, 1 (2007) 7, 456-466, doi:10.3144/expresspolymlett.2007.64

${ }^{10}$ H. M. Laun, Orientation effects and rheology of short glass fiber-reinforced thermoplastics, Colloid \& Polymer Science, 262 (1984) 4, 257-269, doi:10.1007/BF01410464

${ }^{11}$ N. G. Karsli, A. Aytac, Tensile and thermomechanical properties of short carbon fiber reinforced polyamide 6 composites, Composites Part B, 51 (2013) 8, 270-275, doi:10.1016/j.compositesb.2013. 03.023

${ }^{12}$ X. H. Zhang, H. Yang, H. Zhang, C. Y. Wang, A carbon fiber reinforced nylon 6 (CFRPA6) composite specialized for military field cooking task, Applied Mechanics and Materials, 224 (2012) 199-203, doi:10.4028/www.scientific.net/AMM.224.199

${ }^{13}$ C. E. Pelin, A. Stefan, I. Dincă, A. Ficai, G. Pelin, E. Andronescu, D. Constantinescu, G. Voicu, Polyamide 6/carbon fiber laminated composites, Journal of Optoelectronics and Advanced Materials, 17 (2015) 5-6, 750-756

${ }^{14}$ E. C. Botelho, L. Figiel, M. C. Rezend, B. Lauke, Mechanical behavior of carbon fiber reinforced polyamide composites, Composites Science and Technology, 63 (2003) 13, 1843-1855, doi:10.1016/ S0266-3538(03)00119-2

${ }^{15}$ A. B. Strong, Fundamentals of composites manufacturing: materials, methods and applications, 2nd ed., Society of Manufacturing Engineers, Michigan 2008, 464

${ }^{16}$ S. Pillay, U. Vaidya, G. M. Janowski, Liquid molding of carbon fabric-reinforced nylon matrix composite laminates, Journal of Thermoplastic Composite Materials, 18 (2005) 6, 509-527, doi:10.1177/ 0892705705054412

${ }^{17}$ A. C. Long, Design and manufacture of textile composites, 1st ed., CRC Press-Woodhead Publishing Ltd., Cambridge 2006, 261

${ }^{18}$ S. P. Wilkinson, J. M. Marchello, N. J. Johnston, Composite Material Impregnation Unit- NASA Technical Memorandum, National Aeronautics and Space Adminstration Langley Research Center, Document no. 107751, 1993, 9-11

${ }^{19}$ K. K. C. Ho, S. R. Shamsuddin, S. Riaz, S. Lamorinere, M. Q. Tran, A. Javaid, A. Bismarck, Wet impregnation as route to unidirectional carbon fibre reinforced thermoplastic composites manufacturing, Plastics Rubber and Composites, 40 (2011) 2, 100-107, doi:10.1179/174328911X12988622801098

${ }^{20}$ European Standard SR EN ISO 527: Plastics - Determination of tensile properties, 2003

${ }^{21}$ European Standard SR EN ISO 14125: Fibre-reinforced plastics composites - Determination of flexural properties, 2001

${ }^{22}$ U. Vaidya, Composites for Automotive, Truck and Mass Transit: Materials, Design, Manufacturing, DEStech Publications, Pennsylvnia 2011, 82

${ }^{23}$ V. Gudkova, A. Krumme, Influence of addition of MWCNT on PA6 solubility in formic acid and solution viscosity properties, Functional Materials and Technologies Conference, University of Tartu and Tallinn University of Technology Doctoral School, 2013
${ }^{24}$ M. A. Calin, N. Khenoussi, L. Schacher, D. Adolphe, L. R. Manea, I. Gradinaru, I. Zetu, S. Stratulat, Morphological and broadband dielectric spectroscopy approaches on PA6 - CNT nanofibres, Materiale Plastice, 50 (2013) 4, 225-229

${ }^{25}$ S. S. Bhattacharya, A. Mandot, Polyamide/clay nanocomposites film, synthesis and mechanical testing, International Journal of Pure and Applied Sciences and Technology, 17 (2013) 2, 36-44

${ }^{26}$ María Monserrat de La Luz García Curiel, Polymer - Inorganic nanocomposites. Influence of colloidal silica, $\mathrm{PhD}$ Thesis, University of Twente, Netherlands 2004

${ }^{27}$ A. El-Gendi, H. Abdalla, S. Ali, Construction of ternary phase diagram and membrane morphology evaluation for polyamide/formic acid/water system, Australian Journal of Basic and Applied Sciences, 6 (2012) 5, 62-68

${ }^{28}$ T. Brocks, M. Y. Shiino, M. O. Hilário Cioffi. H. J. C. Voorwald, A. Caporalli Filho, Experimental RTM manufacturing analysis of carbon/epoxy composites for aerospace application: non-crimp and woven fabric differences, Materials Research, 16 (2013) 5, 1175-1182, doi:10.1590/S1516-14392013005000107

${ }^{29}$ K. Nishikida, J. Coates, Infrared and Raman analysis of polymers, in: Handbook of plastics analysis, Marcel Dekker Inc., New York 2003, 256-258

${ }^{30} \mathrm{~J}$. Coates, Interpretation of infrared spectra, a practical approach, in: Encyclopedia of analytical chemistry, John Wiley \& Sons Ltd, Chichester 2000, 10815-10837

${ }^{31}$ M. Porubska, O. Szöllos, A. Kónová, I. Janigová, M. Jasková, K. Jomová, I. Chodák, FTIR spectroscopy study of polyamide-6 irradiated by electron and proton beams, Polymer Degradation and Stability, 97 (2012) 4, 523-531, doi:10.1016/j.polymdegradstab.2012. 01.017

${ }^{32}$ S. A. Curran, N. S. Murthy, S. M. Aharoni, H. Minor, Premelting crystalline relaxations and phase transitions in nylon 6 and 6,6 , Macromolecules, 24 (1991) 11, 3215-3220, doi:10.1021/ ma00011a027

${ }^{33}$ M. Dawood, M. Guddati, S. Rizkalla, Effective splices for a carbon fiber-reinforced polymer, Transportation Research Record: Journal of the Transportation Research Board, 2131 (2009), 125-133, doi:10.3141/2131-12

${ }^{34} \mathrm{D}$. Purslow, The shear properties of unidirectional carbon fibre reinforced plastics and their experimental determination Aeronautocal Research Council Current Papers, Paper No. 1381, 1977, 7-9

${ }^{35}$ Plasticomp, Product Data Sheet, Complēt@ LCF50-PA6, Minnesota, USA 2014

${ }^{36}$ Plasticomp, Product Data Sheet, Complēt® LCF30-PA6, Minnesota, USA 2014

${ }^{37}$ RTP Company, Product Data Sheet \& General Processing Conditions, RTP 287 A Nylon 6 (PA) Carbon Fiber, Minnesota, USA 2014

${ }^{38}$ M. C. Campos, C. A. Soufen, M. P. Bueno, M. Imaizumi, Comparative study of mechanical properties of woven of carbon fiber twill and plain weave in laminates with epoxy matrix, 2nd Brazilian Conference on Composite Materials - BCCM2, São José dos Campos-SP, Brazil 2014

${ }^{39}$ S. K. Deb \& Chiranjeevee, Revealing of failure modes of FRP composite by microscopic technique, Bachelor's Degree Thesis, Department of Metallurgical and Materials Engineering, National Institute of Technology Rourkela 2008

${ }^{40}$ E. S. Greenhalgh, M. J. Hiley, Fractography of polymer composites: Current status and future issues, Proc. of the 13th European conference on composite materials (ECCM13), Stockholm, Sweden 2008 